\title{
Embryonic development of the striped spiny eel, Mastacembelus pancalus (Hamilton, 1822) in captive condition
}

\author{
Md. Sherazul Islam* and Tandra Rani \\ Department of Fisheries and Marine Bioscience, Jashore University of Science and Technology, Jessore-7408, Bangladesh
}

Received: May 8, 2020; Revised: October 8, 2020; Accepted: Oct 26, 2020

\begin{abstract}
The striped spiny eel, Mastacembalus pancalus is one of the common food fish in Bangladesh, but lacking study on embryonic development of the fish. The present study describes the embryonic progress stages of the fish in the confined state. The embryogenesis is divided into seven major phases: Zygote phase, Cleavage phase, Morula phase, Blastula phase, Gastrula phase, Organogenesis phase and Hatching phase. According to distinct development characteristics, the further substages were also developed whenever possible. Fertilized eggs were sticky, colorless, and demersal with identical perivitelline space. The thickness of the unfertilized eggs ranged from 0.55-0.58 mm, which increased to $0.62-0.71 \mathrm{~mm}$ in fertilized eggs. The perivitelline space development happened at $0.35 \mathrm{~h}$ after fertilization (AF). The first cleavage groove occurred at the animal pole (two cells) $0.55 \mathrm{~h} \mathrm{AF}$. The added cell division such as four cells, eight cells, sixteen cells, thirtytwo cells, and multi cells stages was initiated at 1.25, 1.45, 2.15, 2.50, and $4.40 \mathrm{~h}$ AF respectively. The morula, blastula, gastrula, yolk plug stage, and organogenesis stages were seen at 8.25, 11.30, 17.15-23.50, 29.20, and 34.15-35.30 h AF respectively. The initial heartbeat was observed at $34.00 \mathrm{~h} \mathrm{AF}$. The head and tail ends of the embryo were distinguished at $35.00 \mathrm{~h}$ AF. The notochord was also evident at the same hours. The embryo started to hatch at $36.00 \mathrm{~h}$ AF which accomplished $39.00 \mathrm{~h}$ at $29.11 \pm 0.29^{\circ} \mathrm{C}$. The new hatchling was $1.65 \pm 0.15 \mathrm{~mm}$ in average length. The present findings will serve as baseline information to develop the breeding protocol of the species in the hatchery condition.
\end{abstract}

Keywords: Embryogenesis, cleavage, organogenesis, hatching

\section{Introduction}

The Guchibaim (Mastacembelus pancalus) is one of the regular food fish found in Asian countries, namely in India, Pakistan, Bangladesh, and Nepal (Talwar and Jhingran, 1991; Froese and Pauly, 2006) and recognized as a striped spiny eel. The species is a common and demandable food fish in Bangladesh and is locally known as 'guchi baim.'

In the past, the fish was available in estuaries and freshwater habitats throughout Bangladesh (Ali, 1967). With the destruction of natural habitat including overexploitation, the fish has diminished abruptly from wildlife (Afroz et al., 2014). Besides drying up of downcast land and using pesticides, the ordinary production lands of this fish are in threat (Rahman et al., 2009). Besides these, the fish is collected only from nature that exaggerates the natural reduction of the fish.

The fish is critically endangered in Bangladesh (FISHWISE, 2013) but has not been shown in the red list of IUCN (Anonymous, 2006). It is needed for the management of natural habitat or to introduce artificial propagation as well as culture. Thus, it is essential to realize the embryonic development stages of the fish to set up a non-natural propagation in a confined condition, it's stocking at mass scale for its expansion and conservation.
Study on biology and breeding has been done on different eel fishes such as on Mastacembelus pancalus (Hasan et al., 2016; Karim and Hossain, 1972); M. armatus (Serajuddin and Mustafa, 1994); Macrognathus aculeatus (Das and Kalita, 2003); M. pancalus (Suresh et al., 2006). The development of egg and/or larvae on eel fishes like M. pancalus (Rahman et al., 2009; Afroz et al., 2014), M. aculeatus (Sahoo et al., 2007; Farid et al., 2008); Muraenesox cinereus (Umezawa et al., 1991); Anguilla rostrata (Oliveira and Hable, 2010); Mastacembelus mastacembelus (Sahinoz et al., 2006) have done, but there are no details of basic work on embryogenesis of $M$. pancalus except Rahman et al. (2009). As the embryonic development process differs from species to species, it is important to know the detailed developmental stages of any fish to consider the artificial propagation of the fish in captivity. It is an urgent need to develop a captive breeding protocol of the species due to the declination of natural propagation. It is essential to know the variations of features in embryonic development and to know the development of organs for the management and rearing technology for seed production of any fish species. Thus, detailed embryonic developmental stages with prominent features were carried out in the captive condition of M. pancalus.

\footnotetext{
* Corresponding author e-mail: dms.islam@just.edu.bd.

** Abbreviations : AFAfter fertilization; EM Egg membrane ; VM Vitelline membrane ; PS Perivitelline space
} 


\section{Materials and Methods}

\subsection{Study site and preparation of aquarium}

The experiment was carried out in the laboratory of the Department of Fisheries and Marine Bioscience, Jashore University of Science and Technology, Jashore, Bangladesh. The experiment was done in rectangular glass aquaria (3 $\mathrm{f}$ length $\times 1.16 \mathrm{f}$ width $\times 1.25 \mathrm{f}$ depth), each containing thirty liters of water. Water hyacinths were used as a source of plants, and their roots were used as a substrate to lay the eggs of the fishes. The major physiochemical parameters like temperature, $\mathrm{pH}$, and $\mathrm{DO}$ were measured at each two hours interval during embryonic development. A pH meter (EZODO, 7200, Taiwan) and a DO meter (LTLutron YK-22DO, Taiwan) were used to measure the water $\mathrm{pH}, \mathrm{DO}$ and temperature respectively.

\subsection{Collection of egg}

In the same laboratory, eggs of $M$. panclaus were produced by inducing with PG hormone. Brood fishes were collected from the nearby natural habitat (Baor) and the average body weight was $9 \mathrm{~g}$ of each. There were three treatments, and each had two more replications for the inducing of the fish. Three pairs of broods were kept 1:1 (male: female) the ratio in each aquarium for natural propagation after inducing. Fishes were spawned (100\%) within sixteen to twenty hours after the administration of the hormone. The sticky eggs of the $M$. pancalus were attached to the aquatic weeds and sometimes on the substrates. Eggs were sampled softly either along with the roots of the water hyacinth or using a father in each sampling.

\subsection{Observation of embryonic development}

The embryonic development stages were observed, and a snap was taken with a photographable microscope (Carl Zeiss microscopy GmbH, S.N. MKG8639, Germany). The eggs were observed at every 5 to 10 minutes interval till the accomplishment of the morula and then after observed each one-hour intermission until hatching. The diameter of oocytes and eggs was measured at each sampling time using the microscopic camera. The development stages and characteristics were confirmed by following Sahoo et al. (2007), Rahman et al. (2009), and Honji et al. (2012).

\section{Results}

\subsection{Aquarium environment}

Water parameters play a major role in the spawning, embryonic development, and hatching of any fish species. In the present study, the physicochemical condition of spawning aquaria such as temperature, dissolved oxygen, and $\mathrm{pH}$ ranged from 28.8 to $29.4^{\circ} \mathrm{C}$, 5.25 to $5.75 \mathrm{mg} . \mathrm{L}^{-1 \text {, }}$ and 7.75 to 8.12 respectively.

\subsection{Characteristics of the egg}

The yellowish eggs were spherical, demersal, and adhesive. They stuck to the roots of water hyacinth in the aquarium. The unfertilized eggs were opaque while the fertilized eggs were transparent with visible egg membrane and yolk (Figure 1A, 1B). The diameter of the fertilized eggs increased 0.62 to $0.71 \mathrm{~mm}$ from 0.55 to $0.58 \mathrm{~mm}$ of the unfertilized egg.

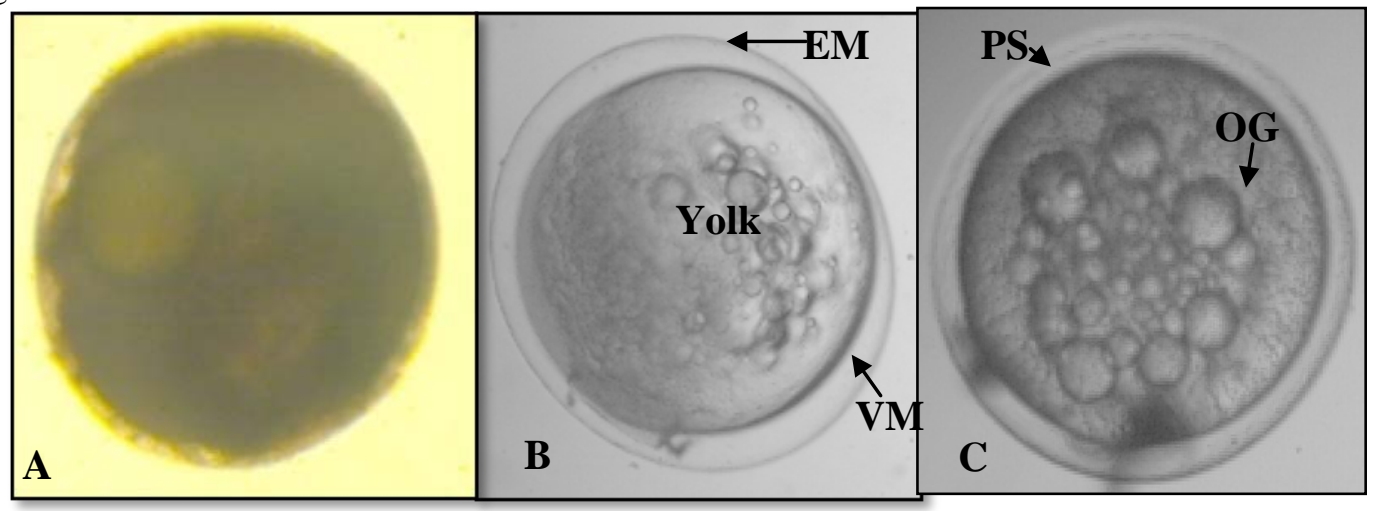

Figure 1. The unfertilized (A) and fertilized (B) egg of M. pancalus. The formation of perivitelline space (C) at the early stage of the zygote. $\mathrm{EM}=$ Egg membrane; $\mathrm{VM}=$ Vitelline membrane; $\mathrm{PS}$ = perivitelline space; OG = oil globule.

\subsection{Embryonic development}

After the fertilization of eggs, the embryonic period started and ended at the time of accomplishment of the general organ systems is common in all fishes. The fertilized eggs hatched out within 36 to $39 \mathrm{~h}$ after fertilization (AF). The events in embryonic progress and their respective time and features of $M$. pancalus are presented in table 1 and figure 1-4. 
Table 1. Embryonic developmental stages (major and sub-phases) with the respected time and features of M. pancalus in aquarium condition.

\begin{tabular}{|c|c|c|c|c|}
\hline Major phase & Sub-phase & Figure & Time (h/min) & Developmental features \\
\hline \multirow{2}{*}{$\begin{array}{l}\stackrel{0}{0} \\
\text { on } \\
\text { N }\end{array}$} & Fertilized eggs & \multirow{2}{*}{1} & 0.00 & Eggs adhesive, demersal, spherical, and transparent. \\
\hline & $\begin{array}{l}\text { Previtteline space } \\
\text { formation }\end{array}$ & & $0.25-0.30$ & Formation of perivitelline space around the yolk \\
\hline \multirow{6}{*}{ 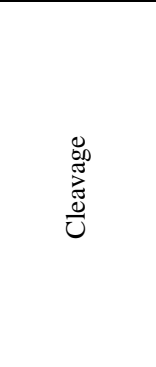 } & Blastodisc & \multirow{6}{*}{2} & 0.35 & Formation of blastodisc at the animal pole \\
\hline & Two cell & & $0.40-0.50$ & $\begin{array}{l}\text { Aggregated oil globules at the animal pole, the commencement of the first } \\
\text { cleavage }\end{array}$ \\
\hline & Four cell & & 1.25 & $2^{\text {nd }}$ cleavage, 4 -cell \\
\hline & Eight cell & & $1.25-1.45$ & The blastomeres were unequal in size and remain in two rows. 8-cell \\
\hline & Sixteen cell & & 2.15 & $4^{\text {th }}$ cleavage, 16 -cell \\
\hline & Multi-cell & & $3.00-4.40$ & $\begin{array}{l}\text { Quick successive division and transformed into } 32,64,128 \text { celled stage and } \\
\text { so on }\end{array}$ \\
\hline$\frac{\frac{\pi}{3}}{\stackrel{0}{0}^{\circ}}$ & & \multirow{5}{*}{3} & $7.15-8.25$ & Formed a cap at the animal pole, which gradually increased in size. \\
\hline $\begin{array}{l}\frac{\pi}{J} \\
\frac{\vec{n}}{\tilde{D}} \\
\frac{\pi}{n}\end{array}$ & & & $11.30-14.45$ & The marginal blastomeres lost their boundaries and were compressed. \\
\hline \multirow{3}{*}{ 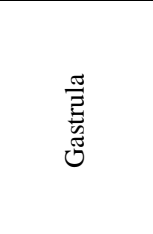 } & Early gastrula & & 17.15 & $\begin{array}{l}\text { Blastoderm started to form a thin layer by invading the yolk and } \\
\text { overthrowing over the yolk }\end{array}$ \\
\hline & Middle gastrula & & 22.10 & $\begin{array}{l}\text { Development of germinal ring in the region of yolk and about } 1 / 2 \text { of the yolk } \\
\text { was possessed by blastoderm. }\end{array}$ \\
\hline & Late gastrula & & 23.50 & The embryonic shield was visible and the blastoderm covered 3/4 of the yolk. \\
\hline \multirow{3}{*}{ 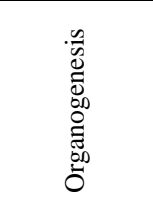 } & Embryonic body & \multirow{4}{*}{4} & 27.15 & The embryonic body was visible. \\
\hline & Yolk plug & & 29.20 & $\begin{array}{l}\text { Finished yolk invasion, visible undeveloped head and tail and became } \\
\text { differentiated. }\end{array}$ \\
\hline & Segmentation & & 34.15- 35.35 & $\begin{array}{l}\text { Distinguished head and tail, and notify of beating heart. Noticeable notochord } \\
\text { in cellular structure. }\end{array}$ \\
\hline 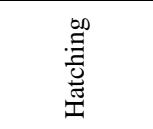 & & & $36.00-39.00$ & $\begin{array}{l}\text { The twisting movement became more forceful and the embryo broke the egg } \\
\text { pod. }\end{array}$ \\
\hline
\end{tabular}

\subsubsection{Zygote phase}

This phase is characterized by fertilized and perivitelline space formation. The perivitelline space formation occurred at $0.30 \mathrm{~h} \mathrm{AF}$ in the present study. The perivitelline space (the thin space that separated the egg membrane) was fluid-filled and equal all around the egg membrane (Figure 1C). Oil globules were visible in the yolk in this phase.

\subsubsection{Cleavage phase}

The single-cell stage became clear with the accumulation of cytoplasm over the animal pole as a protrusion at $0.35 \mathrm{~h} \mathrm{AF}$ representing the early blastodisc or germinal disc stage (Figure 2A). As the development proceeded, the oil globules were found to aggregate and the cytoplasmic disc became thick and the first cleavage occurred within 1.00 to $1.25 \mathrm{~h} \mathrm{AF}$. The vertical cleavage occurred which divided the blastodisc into two different cells at $0.50 \mathrm{~h} \mathrm{AF}$ (Fig. 2B). The further cleavage was at a right angle to the first and observed forming four cells within $1.25 \mathrm{~h}$ (Figure 2C). Further division of blastomere took place with the advancement of time to reach eightcell and sixteen cell stages at $1.45 \mathrm{~h}$ and $2.15 \mathrm{~h} \mathrm{AF}$ respectively (Figure 2D, 2E). After quick succession, the sixteen-celled stages resolved into 32, 64, 128 celled stages, and so on. However, due to the rapid occurrence of these cell divisions, it was not possible to observe or count the stages; and hence in the present study, it was considered as a multi-celled stage (Figure 2F). Eggs were measured and noticed the same size $(0.62-0.71 \mathrm{~mm})$. 

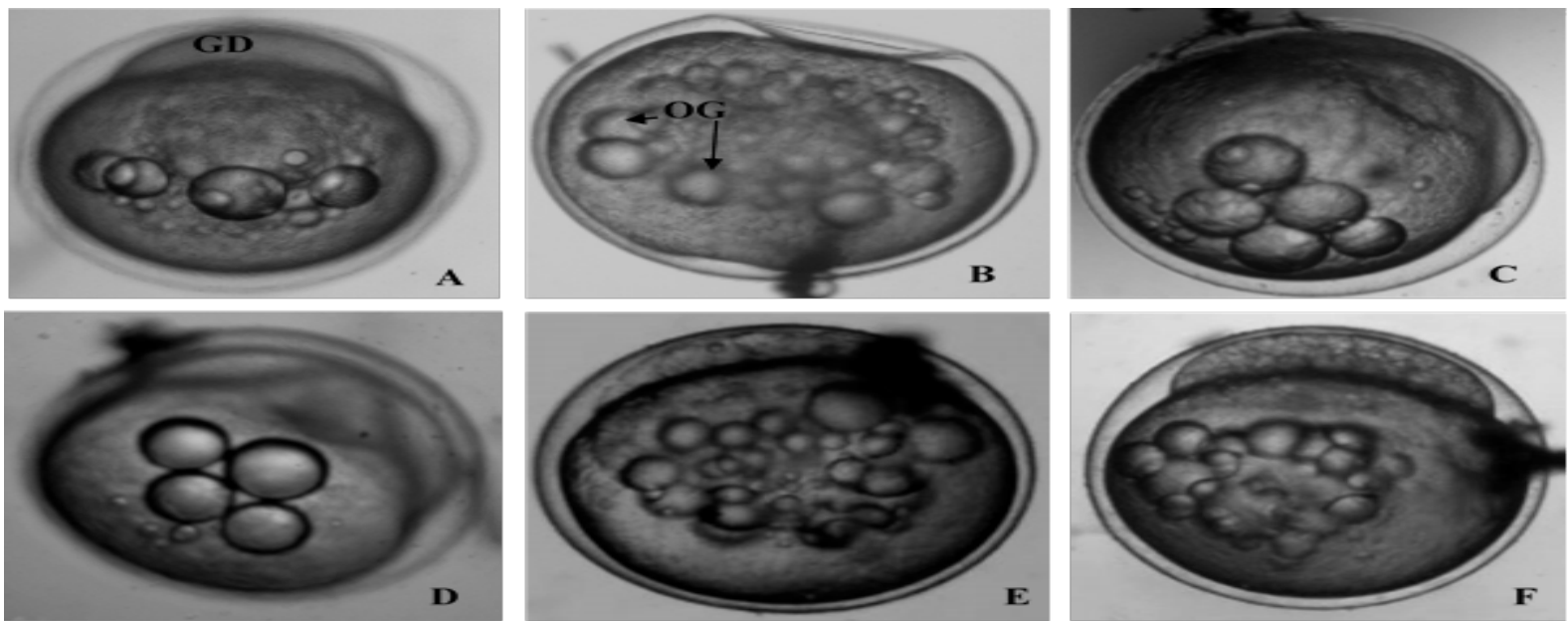

Figure 2. The cleavage phase of M. pancalus; Formation of blastodisc (A), 2-cell (B), 4-cell (C), 8-cell (D), 16-cell (E), and Multi-cell stage (F). GD=Germinal disc (blastodisc); OG=Oil globule.

\subsubsection{Morula phase}

The blastomeres were reduced in size and accumulated around the animal pole during the morula stage. A cap-like creation was seen at the animal pole, which size increased slowly (Figure 3A). The morula phase was recognized at $8.25 \mathrm{~h} \mathrm{AF}$.

\subsubsection{Blastula phase}

The embryo was further divided into numerous cells after the morula and formed a blastoderm by arranging a form of a layer (Figure 3B). The blastodisc was formed by the gradual formation of several layers due to further cell division. At this phase, blastocoels also appeared (a space between yolk and blastoderm). This phase of the embryo is
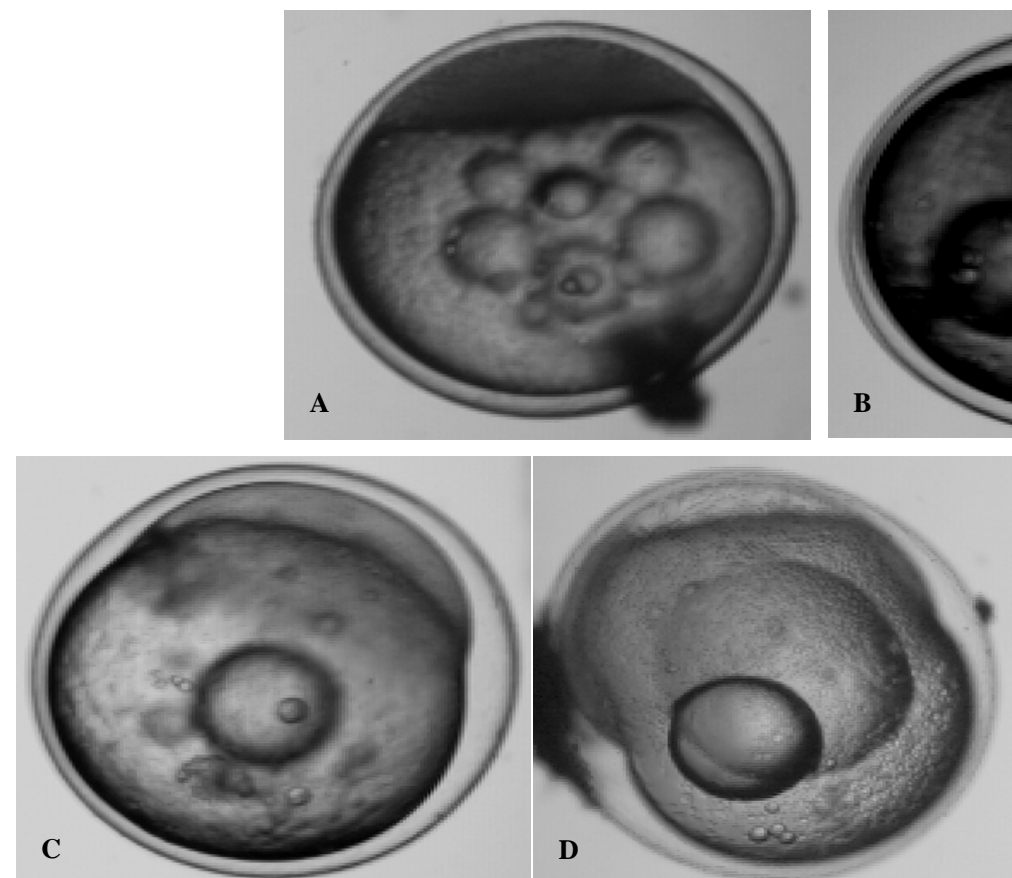

Figure 3. The morula (A), blastula (B) and gastrula phase (C, D, E) of $M$. pancalus; $\mathrm{C}=$ Early gastrula, $\mathrm{D}=$ Middle gastrula and $\mathrm{E}=\mathrm{Late}$ gastrula.

\subsubsection{Organogenesis phase}

The embryonic body formation appeared at $27.15 \mathrm{~h} \mathrm{AF}$ (Figure 4A). The gradual spreading above the germ layer in the plug stage completed the yolk incursion. The head and tail seemed in this stage within $29.20 \mathrm{~h} \mathrm{AF}$ (Figure
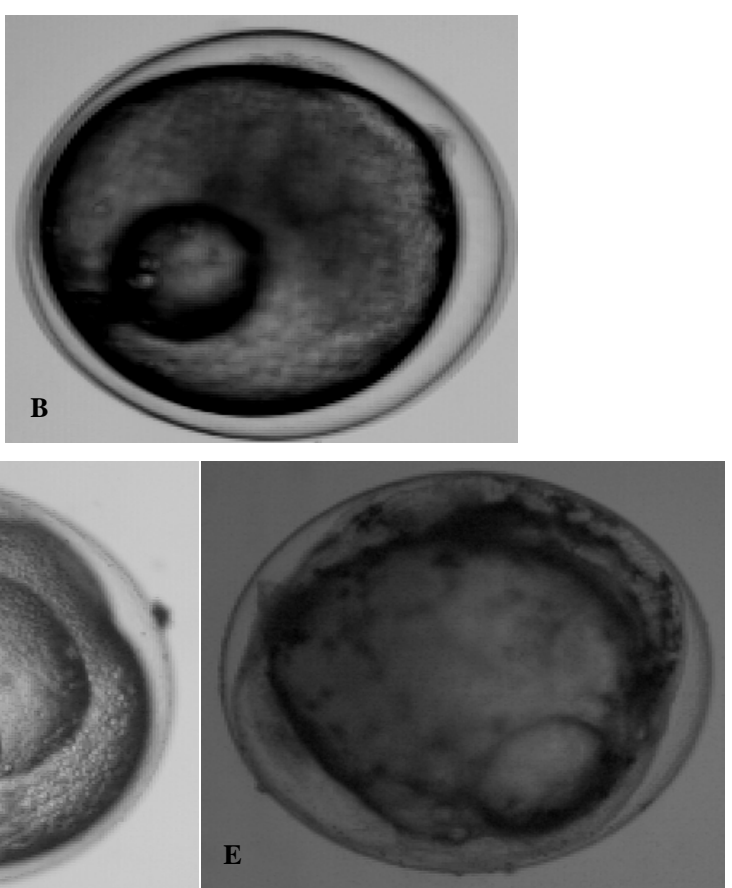

called 'blastula' which was observed within $11.30 \mathrm{~h}$ to 14.45 h AF.

\subsubsection{Gastrula phase}

The gastrulation phase is subdivided into three stages: like early gastrula, middle gastrula, and late gastrula. The incursion of the yolk started by blastoderm through spreading over the yolk like a thin layer which is denoted as the early gastrula and resulted within $17.15 \mathrm{~h} \mathrm{AF}$ (Figure 3C). In the middle of gastrulation, noticed a visible germinal ring on every side of the yolk. In this stage, about half of the yolk was engaged by blastoderm (Figure 3D). The embryonic shield was visible at late gastrulation and blastoderm covered $34^{\text {th }}$ of the yolk (Figure 3E).

4B). In addition to this, the embryo was lengthened and bordered the yolk materials and differentiated the tail and head ends (Figure 4C). The first beating heart was visible at about $34.00 \mathrm{~h} \mathrm{AF}$. Within the cellular structure, the notochord became noticeable within 34.15 to $35.35 \mathrm{~h}$ AF. 

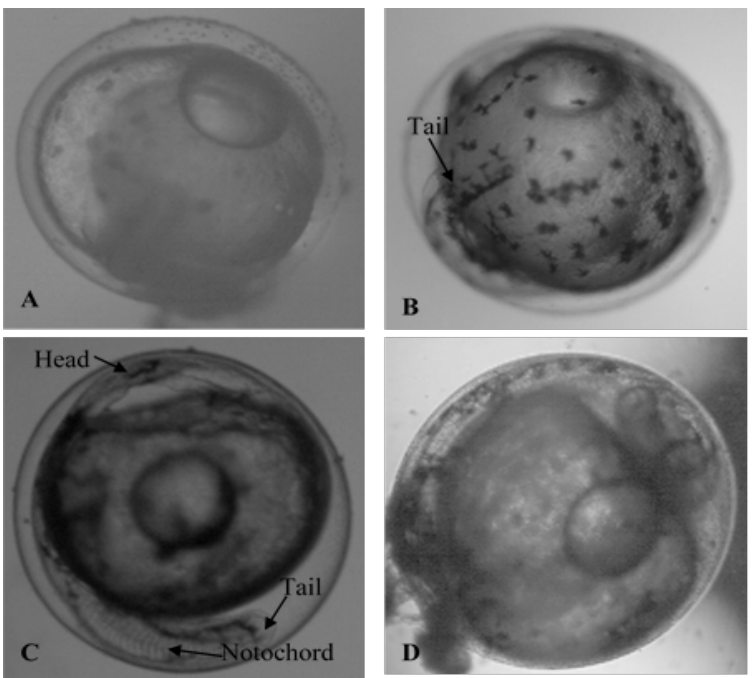
Figure 4. The organogenesis and hatching of $M$. pancalus;
Formation of the embryonic body (A), Yolk plug stage (B), segmentation of organ (C), and just before hatching (D).

\subsubsection{Hatching phase}

In this phase, noticed elongated embryo which progressively separated. The tail became steadily separated from the yolk mass (Fig. 4D). The embryo started an irregular twisting movement. Later, the eggshell started to rupture by the embryos due to the continuous movement. The hatch out of larvae was noticed in 36.00 to $39.00 \mathrm{~h}$ after fertilization with its tail portion first and completed within $3.10 \mathrm{~h}$. The size of the newly hatched larvae was $1.65 \pm 0.15 \mathrm{~mm}$ in length (Fig. 5).

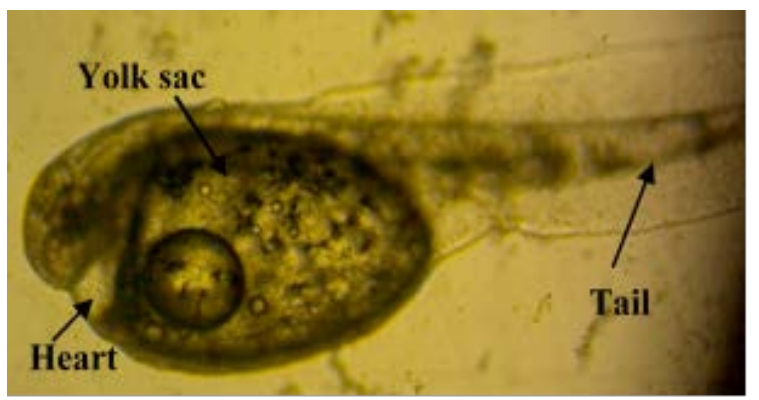

Figure 5. The new hatchling of $M$. pancalus in aquarium condition. Hatching started at $36 \mathrm{~h}$ after fertilization.

\section{Discussion}

\subsection{Aquarium environment}

The embryonic development of fishes is directly related to the water parameters, particularly water temperature. In the present study, the recorded water parameters were deemed suitable for the species. Water temperature during the time of embryonic development was within 28.8 to $29.4{ }^{\circ} \mathrm{C}$ which was close to other studies like 28 to $29^{\circ} \mathrm{C}$ (Sahoo et al., 2007) and $27-31^{\circ} \mathrm{C}$ (Rahman et al., 2009).

\subsection{Characteristics of the egg}

The characteristics of the fertilized and unfertilized eggs are more or less similar to other studies. The unfertilized eggs were dense, demersal, sticky and the fertilized eggs were round, clear, and sticky which is supported by Rahman et al. (2009). Though the same characteristics of fertilized eggs shown in
Mastacembelidae, different egg color such as 'green color' was observed in the case of M. aculeatus (Sahoo et al., 2007). This variation may be due to species variation. The fertilized egg diameter in the present study recorded was 0.62 to $0.71 \mathrm{~mm}$ which was smaller than what was reported by Rahman et al. (2009). They recorded up to 0.70 to $1.30 \mathrm{~mm}$ the size of the fertilized egg in $M$. pancaluss. However, further larger (1.20 to $1.40 \mathrm{~mm}$ ) reported by Sohoo et al. (2007) in M. aculeatus and 1.50 to $2.02 \mathrm{~mm}$ in M. mastacemblus reported by Sahinoz et al. (2006).

\subsection{Embryonic development}

The cell division pattern and the further embryonic development stages were more or less similar to other studies of Mastacembelidae. However, differences were noticed in the case of the time of development in different species and even within the same species. The presence of perivitelline space in the present study was also reported in fertilized eggs of New Zealand freshwater eel, A. dieffenbachia (Lokman and Young, 2000), and Mesopotamian spiny eel, M. mastacembelus (Sahinoz et al., 2006).

The initiation of $1^{\text {st }}$ cleavage, the formation of blastodisc at the animal pole was noticed at $0.35 \mathrm{~h}$ AF which was similar to M. pancalus (Rahman et al., 2009) and M. aculatus (Sahoo et al., 2007). However, in the case of M. mastacemblus it took about $4.00 \mathrm{~h}$ (Sahinoz et al., 2006). In the present study, it was noticed that cell division was completed within about $5.00 \mathrm{~h}$ AF which was almost the same reported by Rahman et al. (2009). However, in the case of $M$. aculatus, the cell division was completed shortly, and it was by 3.30 h AF (Sahoo et al., 2007). Moreover, within the same species, the induction of morula showed at different times. In the present study, the morula stage appeared within $8.25 \mathrm{~h}$ AF whereas Rahman et al. (2009) observed this stage at $10.10 \mathrm{~h} \mathrm{AF}$. According to Sahoo et al. (2007), the same stage in M. aculeatus occurred at $4.10 \mathrm{~h} \mathrm{AF}$. The blastoderm enclosed nearly $3 / 4^{\text {th }}$ of the yolk and an embryonic body was formed 27.15 $\mathrm{h}$ AF which was noticed $24.30 \mathrm{~h} \mathrm{AF}$ in the same species (Rahman et al., 2009) and 25.30h AF in M. aculatus (Sahoo et al., 2007) whereas more time (40h) was taken in the case of M. mastacemblus (Sahinoz et al., 2006).

The formation of the head and tail of the embryo showed 29.20h AF which was observed in $31.30 \mathrm{~h}$ in the same species (Rahman et al., 2009) and even in higher temperatures. However, at a similar temperature, this characteristic was observed at $4.00 \mathrm{~h}$ earlier compared to M. aculatus (Sahoo et al. (2007) and took more than double duration (77h) in M. mastacemblus (Sahinoz et al. 2006). The heart pulsation was noticed during about 34.00 h AF in this study alike to Rahman et al. (2009) but earlier as compared to Japanese eel, A. paponica (Yamamoto et $a l ., 1995)$. The twisting movement and first hatching were observed at $36.00 \mathrm{~h} \mathrm{AF}$. The earlier twisting movement and first hatching were reported by Rahman et al. (2009) in the same species and in similar water temperatures. In the case of other eel fishes, different hatching time was reported like $31.45 \mathrm{~h}$ in M. aculatus (Sahoo et al., 2007), 38.00-45.00 h in A. paponica (Yamamoto et al., 1995) and 85.00 h in M. mastacemblus (Sahinoz et al., 2006).

In the present study, it was strong evidence that quick development happens until morula compared to other 
studies, but later stages took a longer period particularly in organogenesis and hatching (Figure 6). This may be due to temperature variation as compared to Rahman et al. (2009) who recorded more than $30^{\circ} \mathrm{C}$ after gastrulation whereas in the present study it was less than $30^{\circ} \mathrm{C}$. The other variability like the formation of morula and head and tail due to the different rates of development in different species in addition to temperature.

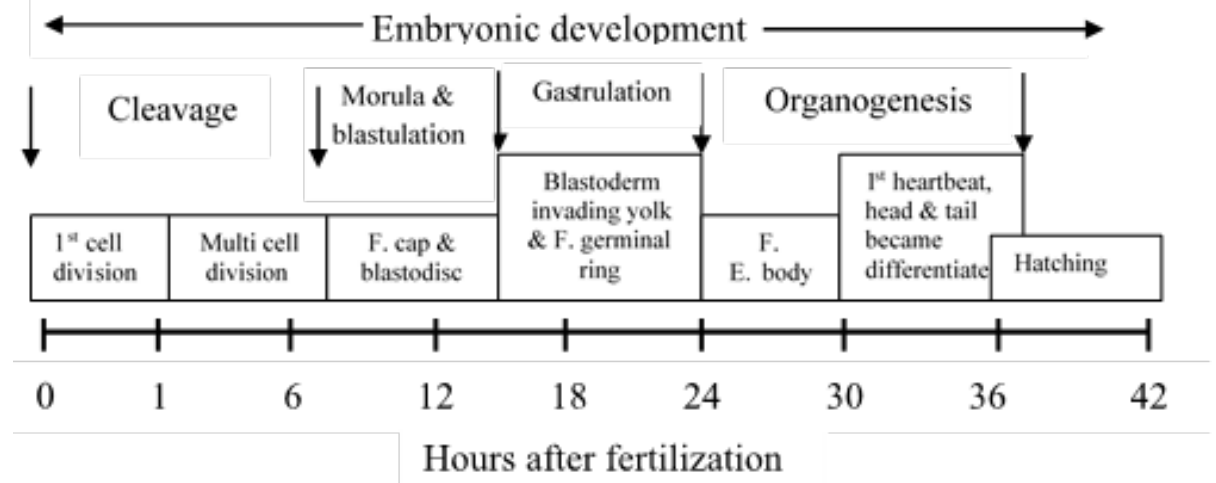

Figure 6. Major events during the embryonic development of $M$. pancalus. $\mathrm{C}=$ completion, $\mathrm{F}=$ formation, $\mathrm{E}=\mathrm{Embryonic}$

\section{Conclusion}

The study generated detailed information on early developmental commencement with distinguishing characteristics of $M$. pancalus. In conclusion, it is said that the embryonic development of $M$. pancalus commonly imitates that of other eel fishes. However, the period of development varies in some stages. Besides, the development rate of the embryo varied in the variation of water temperature. The development process is noticed faster in the higher the temperature, and vice versa.

\section{Acknowledgement}

The present study was financially supported by the Grant for Advanced Research in Education (GARE), Ministry of Education, People's Republic of Bangladesh. We also thank other groups of the project who successfully breed the species in the aquarium by inducing and providing us with the eggs for further study.

\section{References}

Afroz A, Islam MS, Hasan MR, Hasnahena M and Tuly DM. 2014. Larval rearing of spiny eel, Mastacembelus pancalus in the captivity with emphasis on their development stages. Int J Fish Aquat Stud, 1(6): 163-167.

Ali MH. 1967. Induced breeding of major carps in ponds by pituitary hormone injection. Agricultural Information Service, Dhaka. pp. 23-26.

Anonymous. IUCN red list of threatened species (2006) International Union for Conservation of Nature. http://www.redlist.organization (January 2019).

Das SK and Kalita N. 2003. Captive breeding of peacock eel, Macrognathus aculeatus. Aquac Asia, 8: 17-21.

Farid SM, Miah MI, Akter MD, Saha D and Rahman MM. 2008. Embryonic and larval development of tarabaim (Macrognathus aculeatus). J Agrofor Env, 2(2): 123-129.

FISHWISE, http:/ www. Fishwise. Co.za, Species= Mastacembelus pancalus 5 January,2013.

Froese R and Pauly D. (eds), 2006. Fishbase, World-wide-Web Electronic publication. http://www.Fishbase.org
Hasan MR, Islam MS, Afroze A, Bahdur P and Akter S. 2016. Captive breeding of Striped Spiny Eel, Mastacembelus pancalus (Hamilton, 1822) considering the various hormonal responses. Int J Fish Aquat Stud, 4(3): 07-11.

Honji MR, Tolussi CE, Mello PH, Caneppele D and Moreira RG. 2012. Embryonic development and larval stages of Steindachneridion parahybae-implications for the conservation and rearing of this endangered Neotropical species. Neotrop Ichthyol, 10(2): 313-327.

Karim MA and Hossain A. 1972. Studies on the biology of Mastacembelus pancalus (Spiny Eel, Hamilton) in artificial pond. Part II. Sexual maturity and Fecundity. Bangladesh J Agric Bio Sci, 1(2):15-18.

Lokman PM and Young G. 2000. Induced spawning and early ontogeny of New Zealand freshwater eels (Anguilla dieffenbachii and A. australis). NZ J Mar Freshwater Res, 34: 135-145.

Oliveira K and Hable WE. 2010. Artificial maturation, fertilization, and early development of American eel (Anguilla rostrata). Can J Zool, 88:1121-1128.

Rahman MM, Miah MI, Taher MA and Hasan MM. 2009. Embryonic and larval development of guchibaim, Mastacembelus pancalus (Hamilton). J Bangladesh Agril Univ, 7 (1): 193-204.

Sahinoz E, Dogu Z and Aral F. 2006. Development of embryos in Mastacembelus mastacembelus (Bank \& Solender 1794) (Mesopotamian spiny eel) (Mastacembelidae). Aquac Res, 37: 1611-1616.

Sahoo SK, Giri SS, Shaha A, Chandra S, Sahu AK and Sarangi N. 2007. Embryonic development of the spiny eel, Mastacembelus aculeatus (Bloch, 1786). Indian J Fish, 54(3): 333-337.

Serajuddin M and Mustafa S, 1994. Feeding specialization in adult spiny eel, Mastacembelus armatus. Asian Fish Sci, 7(1):6365.

Suresh VR, Biswas BK, Vinci GK, Mitra K and Mukherjee A. 2006. Biology and fishery of barred spiny eel, Macrognathus pancalus (Hamilton). Acta Ichthyol Piscat, 36 (1): 31-37.

Talwar PK and Jhingran AG. 1991. Inland Fishes of India and Adjacent Countries. Calcutta: Oxford and IBH Publishing.

Umezawa A, Otake T, Hirokawa J, Tsukamoto K and Okiyama M. 1991. Development of the eggs and larvae of the pike eel, Muraenesox cinereus. Jpn J Ichthyol, 38(1):35-40.

Yamamoto K, Yamauchi K and Kasuga S. 1975. On the development of the Japanese eel, Anguilla japonica. Bull Japan Soc Sci Fish, 41(1): 21-28. 